\title{
Macular edema in multiple evanescent white dot syndrome
}

\author{
Edema macular na síndrome dos múltiplos \\ pontos brancos evanescentes
}

Raul N. G. Vianna ${ }^{1,2}$, André Soares Maia', Leticia Rielo de Moura ${ }^{1}$, Ana Lúcia Peixoto', Hugo Soares Maia ${ }^{1}$

\begin{abstract}
Eletroretinographic findings show that the transient decreased vision seen in patients with the multiple evanescent white dot syndrome (MEWDS) is related to metabolic disturbances at the level of the retinal pigment epithelium and photoreceptor complex. In this paper, we present a patient with a typical picture of MEWDS associated to macular edema, which could also be a factor to reduce vision in this disorder. Case report of a 53-year-old woman complaining about unilateral decreased vision of 7 days' duration was sent to our retina clinic. A complete ophthalmic examination was performed as well as fluorescein angiography, indocyanine green angiography, Goldmann visual fields and optical coherence tomography (OCT). Best-corrected visual acuity was 20/ 40 and 20/20, in the right and left eye respectively. Ophthalmoscopy of the affected eye revealed multiple focal outer retinal gray lesions in the perimacular and peripapillary region. There were several orange puntate lesions in the foveolar region. Fluorescein angiography disclosed faint multiple foci of staining in the perimacular and peripapillary area, and some staining of the optic disc. A discrete hyperfluorescence was also observed in the foveal region. OCT disclosed an increase in foveal thickness $(231 \mu \mathrm{m})$, approximately $25 \%$ thicker than the opposite normal eye $(186 \mu \mathrm{m})$. Within 3 months her visual acuity had returned to $20 / 20$ and the foveal thickness returned to a normal value (189 ìm). Although the mechanism of transitory blurred vision is not completely elucidated in cases of MEWDS, we suggest that macular edema may play a role.
\end{abstract}

Keywords: Electroretinography; Macular edema; Retinal diseases; Vision disorders; Syndrome; Case reports

\footnotetext{
${ }^{1}$ Uveitis, Retina and Tumors Unit, Instituto Brasileiro de Oftalmologia - IBOL - Rio de Janeiro (RJ), Brazil;

${ }^{2}$ Department of Ophthalmology, Hospital Universitário Antonio Pedro, Universidade Federal Fluminense - UFF - Niterói (RJ), Brazil;

From the Uveitis, Retina and Tumors Unit, Instituto Brasileiro de Oftalmologia - IBOL - Rio de Janeiro (RJ), Brazil.
}

Recebido para publicação em: 8/12/2009 - Aceito para publicação em 10/2/2010 


\section{INTRODUCTION}

M ultiple evanescent white dot syndrome (MEWDS), initially described in 1984, is an acute, multifocal, usually unilateral retinopathy affecting young adults ${ }^{(1)}$

Eyes with MEWDS usually show several yellowwhite dots at the level of the deep retina or retinal pigment epithelium (RPE). The visual acuity ranges from 20/20 to $20 / 40$ and most patients complain of the presence of a scotoma and associated photopsias ${ }^{(1)}$. Besides the typical retinal lesions, a characteristic granular appearance to the fovea is present acutely, and the fovea usually does not return to a normal appearance ${ }^{(1)}$. The exact mechanisms of visual loss in MEWDS are not well understood but may represent photoreceptor, RPE, and optic nerve dysfunction.

In this paper we present the optic coherence tomography (OCT) findings of a patient with active MEWDS. Based on these findings we suggest that macular edema may play a role in the transitory decreased visual acuity seen in patients with this disorder.

\section{Case report}

A 53-year-old woman noted photopsia and blurred vision in her right eye. Her visual acuity was $20 / 40$ in the right eye (RE) and 20/20 in the left eye (LE). Biomicroscopic examination revealed a mild inflammatory reaction $(+/ 4$ cells $)$ in the anterior chamber of the RE. The intraocular tension was inside normal limits in both eyes. The vitreous humor showed a few cells (trace). Ophthalmoscopy of the affected eye revealed multiple focal outer retinal gray lesions in the perimacular and peripapillary region (figure $1 \mathrm{~A}$ ). There were several orange puntate lesions in the foveolar region. Fluorescein angiography disclosed faint multiple foci of staining in the perimacular and peripapillary area, and some staining of the optic disc. A discrete hyperfluorescence was also observed in the foveal region (figure 1B). Indocyanine green angiography (ICG-A) showed multiple nonfluorescent lesions in the choroid and in the peripapillary region, in a pattern similar to the areas of staining in the fluorescein angiogram (figure 1C). Goldmann visual field of the affected eye revealed an enlarged blind spot (figure 1D) and the electroretinogram showed a decreased a-wave. These features supported the diagnosis of MEWDS. To evaluate the macular structure we performed OCT (Zeiss-Stratus 3), which disclosed an increase in foveal thickness $(231 \mu \mathrm{m})$, approximately $25 \%$ thicker than the opposite normal eye $(186 \mu \mathrm{m})$ (figure 2). The total macular volume was 7.73

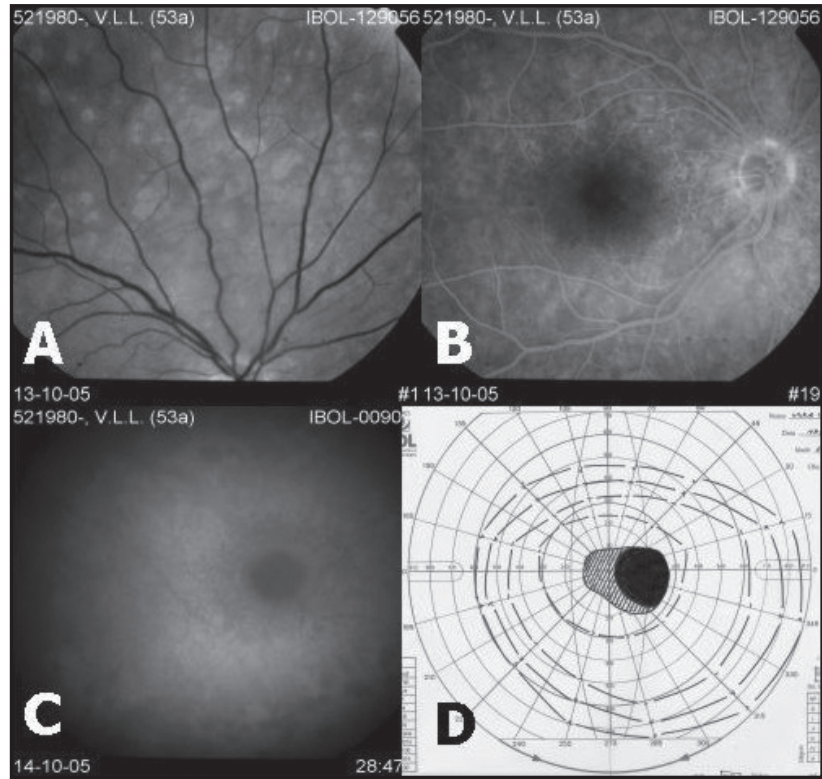

Figure 1: (A)Red-free fundus photograph discloses multiple focal outer retinal gray lesions. The retinal lesions were gradually hyperfluorescent on fluorescein angiography. A discrete foveal hyperfluorescence can also be observed; (B) The lesions are hyperfluorescent on fluorescein angiography and hypofluorescent on indocyanine green angiography (C); Goldmann visual field revealed an enlarged blind spot (D)

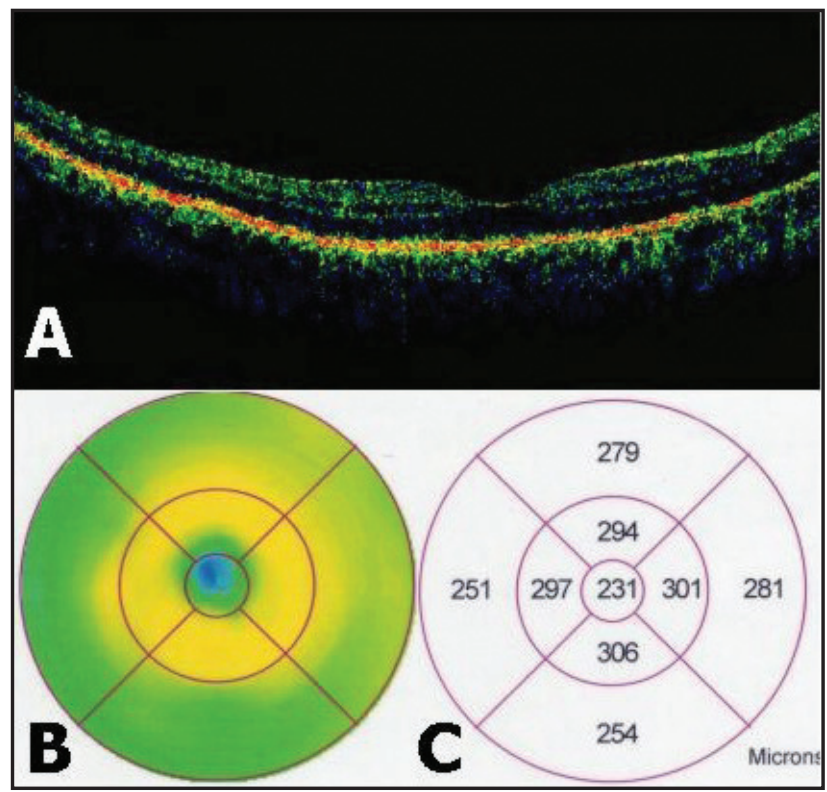

Figure 2: (A) OCT image; note the slight increase in retinal thickness and the lack of foveal depression; (B) Qualitative analysis discloses discrete thickness in the macular region (in yellow color); (C) Quantitative analysis shows a foveal thickness of $231 \mu \mathrm{m}$ (normal: $150-200 \mu \mathrm{m}$ ). The total macular volume was $7.73 \mathrm{~mm}^{3}$ in the affected eye $\left(6.86 \mathrm{~mm}^{3}\right.$ in the normal eye $)$

$\mathrm{mm}^{3}$ in the affected eye and $6.86 \mathrm{~mm}^{3}$ in the normal eye. These features led to the diagnosis of macular edema in the RE. The patient was followed monthly and within 3 
months her visual acuity had returned to 20/20. Foveal thickness and total macular volume also returned to normal values (189 $\mu \mathrm{m}$ and $6,96 \mathrm{~mm}^{3}$ respectively).

\section{Comments}

It has been suggested that the decreased vision observed in eyes with MEWDS may be related to transient metabolic disturbances at the level of the retinal pigment epithelium - photoreceptor complex. Indeed, during the acute phase of the disease, the ERG a-wave and early receptor potential amplitudes are profoundly decreased in most affected patients, which suggests a primary involvement of the outer segments of photoreceptors $^{(2)}$. In addition, Keunen and van Norren have used foveal densitometry and color matching to show that, even in those few patients with normal ERG findings, abnormalities exist during the active stage of MEWDS at the level of the cone photoreceptor outer segments ${ }^{(3)}$. Nevertheless, focal ERG studies revealed delayed recovery of oscillatory potential, which also implies some inner retinal involvement ${ }^{(4)}$.

Using Stratus-OCT III, Chan et al. estimated that the normal foveal thickness was $182 \pm 23 \mu \mathrm{m}^{(5)}$. The OCT of our case disclosed an increase in foveal thickness (231 $\mu \mathrm{m}$, approximately $25 \%$ thicker than the opposite normal eye, $186 \mu \mathrm{m}$ ), supporting the diagnosis of macular edema. It must be pointed out that large differences of the foveal thickness between eyes in patients with macular disease may represent a true derangement from normality. Indeed, it has been shown that there is striking symmetry of the foveal thickness between the eyes of each normal individual ${ }^{(6)}$.

Moreover, varying degrees of intraocular inflammation have been reported in patients with $\operatorname{MEWDS}^{(7)}$. Thus, there is a rationale for the development of inflammatory macular edema in these eyes. Although the mechanism of transitory blurred vision is not completely elucidated in cases of MEWDS, we suggest that macular edema may play a role.

\section{RESUMO}

Propósito: Achados eletroretinográficos revelam que a baixa visual transitória observada em pacientes com a síndrome dos múltiplos e evanescentes pontos brancos na retina (MEWDS) está relacionada a distúrbios metabólicos ao nível do epitélio pigmentado da retina e dos fotorreceptores. No presente artigo, nós apresentamos um paciente com um quadro típico de MEWDS associado a edema macular, o qual pode ser um fator que reduz a acuidade visual. Método:
Relato de caso. Sexo feminino, 53 anos, queixando-se de baixa visual há 7 dias foi encaminhada ao Setor de Retina. Realizado exame oftalmológico completo, que incluiu: angiofluoresceinografia, angiografia com indocianina verde, campo visual de Goldmann e tomografia de coerência óptica (OCT). Resultados: A acuidade visual era de 20/20 e 20/40 nos olhos direito e esquerdo, respectivamente. A oftalmoscopia do olho afetado revelou lesões acinzentadas, múltiplas, profundas, nas regiões perimaculares $e$ peridiscais. A mácula tinha aspecto granulado. A angiografia fluoresceínica revelou hiperfluorescência gradativa das lesões, bem como do nervo óptico. O OCT revelou um aumento da espessura foveal no olho afetado $(231 \mu \mathrm{m})$, aproximadamente $25 \%$ maior que a espessura do olho normal contralateral $(186 \mu \mathrm{m})$. Após 3 meses de evolução sem tratamento, a acuidade visual retornou a 20/ 20 e a espessura foveal já era normal (189 $\mu \mathrm{m})$. Conclusão: Embora o mecanismo de baixa visual transitória não esteja completamente elucidada em MEWDS, nós sugerimos que o edema macular possa ser uma das causas.

\section{RefERENCES}

1. Jampol LM, Sieving PA, Pugh D, Fishman GA, Gilbert H. Multiple evanescent white dot syndrome. I. Clinical findings. Arch Ophthalmol 1984; 102(5):671-4.

2. Sieving PA, Fishman GA, Jampol LM, Pugh D. Multiple evanescent white dot syndrome.II. Electrophysioloy of the photoreceptors during retinal pigment epithelium disease. Arch Ophthalmol. 1984; 102(5):675-9.

3. Keunen JE, Van Norren D. Foveal densitometry in the multiple evanescent white dot syndrome. Am J Ophthalmol. 1988;105(5):561- 2 .

4. Horiguchi M, Miyake Y, Nakamura M, Fujii Y. Focal electroretinogram and visual field defect in multiple evanescent white dot syndrome. Br J Ophthalmol. 1993;77(7):452-5.

5. Chan A, Duker JS, Ko TH, Fujimoto JG, Schuman JS. Normal macular thickness measurements in healthy eyes using Stratus Optical Coherence Tomography. Arch Ophthalmol. 2006;124(2):193-8.

6. Hedge V, James P, Pagliarini S. Foveal thickness analysis using optical coherence tomography (OCT-III) in a normal population of the UK [abstract]. Invest Ophthalmol Vis Sci. 2005;46:E4268.

7. Khurana RN, Albini T, Dea MK, Rao NA, Lim JI. Atypical presentation of multiple evanescent white dot syndrome involving granular lesions of varying size. Am J Ophthalmol. 2005;139(5):935- 7.

\section{Correspondence to:}

Raul N. G. Vianna

Rua General Mariante, $n^{\circ}$ 88/802

CEP 22221-100 - Laranjeiras - RJ

Phone/Fax: 55 (21) 2610-1051

E-mail: raulngvianna@ig.com.br 